UDK 811.162.1'367.332

Izvorni znanstveni članak

Prihvaćeno za tisak: 20. rujna 2019.

https://doi.org/10.22210/suvlin.2019.088.02

\author{
Miroslav Hrdlička \\ Filozofski fakultet Sveučilišta u Zagrebu \\ mhrdlick@ffzg.hr
}

\title{
Povratnost kao imenička kategorija: slučaj poljskih povratnih imenica
}

\begin{abstract}
U radu se istražuju "povratne imenice«, pojava u poljskom jeziku u kojoj pri nominalizaciji glagola s povratnom oznakom się glagolska imenica zadržava povratnu oznaku. Uspoređuju se sintaktička i semantička obilježja povratnih imenica u usporedbi s glagolima od kojih su izvedene te se istražuje njihova uporaba u mrežnom korpusu poljskog jezika. Pokazuje se kako se određena obilježja povratnih glagola, ovisno o vrsti povratnih glagola, prenose i na njihove imeničke parnjake, ali se ističu i neke specifičnosti u tvorbi i uporabi povratnih imenica. Pojava povratnih imenica razmatra se u kontekstu poredbenih opisa slavenskih jezika te njihovih sličnosti i razlika u izražavanju povratnosti.
\end{abstract}

\section{Uvod}

U ovom će radu pozornost biti posvećena kategoriji povratnosti kao strukturnoj gramatičko-leksičkoj pojavi te jezičnim sredstvima kojima se ona iskazuje u poljskom jeziku u usporedbi s hrvatskim ${ }^{1}$. Posvetit ćemo se jednoj specifičnoj kategoriji - onoj tzv. povratnih imenica u poljskom jeziku - koje su važna razlika u odnosu na hrvatski i predstavljaju specifičnu tipološku razliku u odnosu na druge slavenske jezike u kojima nisu prisutne (s izuzetkom češkog). Povratnost ili refleksivnost u najširem jezikoslovnom smislu nalazimo definiranu kao sposobnost jezika da govori o jeziku samom (CODL 2013: 339). Istražujući povratnost iz tipološke perspektive Schladt (1999: 104) zaključuje da je ona univerzalna jezična kategorija te da bi, iako se u različitim jezicima iskazuje na različite načine, različitim oznakama, bilo malo vjerojatno da neki jezik nema način za iskazivanje povratnosti. Međutim, pogledamo li definicije povratnosti u literaturi, možemo uočiti da su one usmjerene ponajviše na pojam 'radnje' kao povratne kategorije, odnosno na glagol kao središnju vrstu riječi kojom se povratnost može izraziti. O tome svjedoče podje-

1 Zahvaljujemo dvama anonimnim recenzentima na pomnom čitanju rada i konstruktivnim savjetima. 
le povratnih glagola u hrvatskim gramatikama i studijama povratnosti (npr. Barić i sur. 2005, Silići Pranjković 2007, Belaj 2001, Oraić Rabušić 2018), u kojima je često naglasak na a) problematičnom statusu određivanja se kao vrste riječi (zamjenice ili čestice) i b) klasifikaciji i razlikama u vrstama povratnih glagola (npr. reflexiva tantum, pravi povratni glagoli, nepravi povratni glagoli i sl.). Nadalje, o ulozi se povratne oznake u strukturi rečenice govori u studijama glagolskoga stanja, posebice vezano uz pasiv i obezličenje, kao u primjerima:

(1) Zato prosvjeduju, jer, kažu, ne mogu živjeti od smrada smeća kad se istovari iz kamiona. (Oraić Rabušić 2018: 175)

(2) a) (Szkoła) jest budowana (przez Jana). 'Škola je građena (od Jana).'

b) (Szkoła) buduje się. ‘Škola se gradi.' (GWJP. Morfologia 1984:140)

Dodatno, bitno je istaknuti da se u gramatičkim opisima navedenih dvaju jezika stavlja različito težište na jezične jedinice koje su temeljni nositelji povratnosti, iako se kao jedan od temeljnih oblika izražavanja povratnosti u poljskom i hrvatskom jeziku ističe povratna oznaka się/se, koja je podrijetlom odraz protoslavenske povratne zamjenice *sę u akuzativu jednine (Matasović 2011: 6). U hrvatskom se povratnost obično promatra u kontekstu glagola kao leksičke i morfosintaktičke kategorije, dok se u poljskom povratnost često tumači u vezi sa sintaktičkim preoblikama glagolskog stanja, uz malobrojne iznimke koje se posvećuju klasama glagola i njihovim razlikama u izražavanju povratnosti (v. Wilczewska 1966). Povratnost kao imenička kategorija nije u središtu jezikoslovnih istraživanja ni jednoga od tih dvaju jezika pa se stoga nameće pitanje kako se njezinim uključivanjem mogu proširiti tumačenja povratnosti u slavenskim jezicima, ali i specifična obilježja koja te jezike razlikuju.

Poljski je specifičan među slavenskim jezicima po tome što produktivno koristi povratnu oznaku się u tvorbi glagolskih imenica, kao u sljedećim primjerima:

(3) Fundamentalnastrategiqu uczenia sięstosowanq̨ przez prawidłowo rozwijajq̨ce się2 dziecko, jest imitacja.

'Temeljna strategija učenja koju primjenjuje dijete koje se pravilno razvija jest imitacija.'

(4) Poznaj najlepszy sposób napozbycie się. $\mathrm{PF}^{3}$ zbędnych kilogramów.

'Upoznaj najbolji način za riješiti se (dosl. rješenje se) suvišnih kilograma.'

2 Kao što je vidljivo u primjeru, i glagolski participi u poljskome mogu zadržavati się, što upućuje na različite načine kojima se povratnost može iskazivati (o glagolskom participu v. Hrdlička i Vidović Bolt 2019). Međutim, ta je tema izvan opsega istraživanja ovoga rada.

3 U radu su korištene sljedeće kratice: PF - svršeni oblik glagola, IPF - nesvršeni oblik glagola, Adj. - pridjev. 
Osim u poljskom, povratne su imenice u manjoj mjeri posvjedočene u češkom jeziku, kao u primjeru (5), ali njihova je tvorba ograničena i nisu produktivna kategorija kao u poljskom.

(5) Petrovo včerejši vysvětlení se.

Peter's yesterday-Adj explanation SE.

('Peter's yesterday explanation himself.') (Hron 2005: 9)

'Petrovojučerašnje objašnjenje *se.'

U istočnoslavenskim jezicima i sama povratna oznaka -sja funkcionira drugačije negoli u zapadnoslavenskim i južnoslavenskim jezicima, ponaša se kao afiks glagolu i nije produktivna kategorija u tvorbi povratnih oblika glagola, npr. rus. kupatsja 'kupati se', rus. zanimatsja 'učiti' (usp. Popović i Trostinska 1991, Letuchiy 2011).

Kao što je iz primjera (3) i (4) vidljivo, u hrvatskome ne postoje povratne inačice glagolskih imenica, unatoč drugim sličnostima u tvorbi i postanku ove kategorije u obama jezicima. Stoga će njihov opis i usporedba s hrvatskim primjerima biti u središtu istraživanja ovoga rada iz nekoliko razloga. Prvo, smatramo da je sustavan opis poljskih glagolskih imenica važno uključiti u šire rasprave o povratnosti kao univerzalnoj jezičnoj kategoriji, pogotovo u vidu pregleda različitih sredstava kojima se povratnost u jezicima svijeta može izraziti. Drugo, budući da je povratnost $u$ dvama istraživanim jezicima promatrana primarno kao glagolska, odnosno, rečenična kategorija, smatramo važnim promotriti načine i razloge njezina prijenosa i funkcioniranja u imeničkoj kategoriji. Cilj nam je time steći nove uvide u narav povratnih glagola kao jedinica koje su temelj svojim imeničkim inačicama, pogotovo zato što je pojam povratnih glagola, kao i glagola kao temeljne jedinice koja je nositelj značenja povratnosti, problematičan u poljskim jezikoslovnim opisima. Treće, budući da »povratne imenice« ne postoje u hrvatskom jeziku, cilj nam je pružiti sustavan opis ove pojave koji svoju primjenu može naći i u poučavanju poljskog jezika i njegovoj usporedbi s hrvatskim. Potonji je cilj ujedno i zanimljiv s poredbenog gledišta jer je riječ o dvama slavenskim jezicima koji dijele mnoge sličnosti, ali pokazuju i neke sustavne razlike u izražavanju povratnosti.

\section{Načini izražavanja povratnosti u poljskom i hrvatskom jeziku}

U oba se istraživana jezika povratnost primarno izriče povratnom oznakom (się/se), preciznije, glagolom uz koji stoji povratna oznaka. Istim se sredstvom mogu izražavati i druga značenja, poput uzajamnosti (6).

(6) Dosyćtej krwi, przestańcie się bić, na obiad, ale już!

'Dosta te krvi, prestanite se tući, na ručak, ali odmah!'

Sama se povratnost može izricati drugim sredstvima, kao što je naglašeni oblik povratne zamjenice sebe ili sintagme poput sam sebe, sam sa sobom. 
Osim zamjenicom/česticom się/se koja se pridjeljuje glagolu ili specijaliziranim sintagmama za izražavanje povratnosti i uzajamnosti radnje, u oba jezika možemo pronaći povratnost pridodanu imenskim kategorijama, zamjenicama i imenicama. To se odnosi na nekoliko pojavnosti. Prva se odnosi na postojanje povratno-posvojne zamjenice swój - svoj. Druga se ostvaruje u složenicama tvorenima sa slobodnom zamjeničkom osnovom u prvom dijelu (najčešće je to samo-) i spojnikom -o-, npr. samobójstwo - samoubojstvo, samoobrona - samoobrana, samokrytyka samokritika4. Kao što S. Babić (2002: 372) navodi, to je plodan tip složenica, ali su mu ograničenja ta da u drugom dijelu dolaze imenice koje najčešće označuju radnju. I u ovim primjerima, kao i u primjerima s glagolskim imenicama, razvidno je da se povratnost i dalje veže ponajprije uz pojam radnje, ali da je posredovana drugačijim procesima nominalizacije. Međutim, iz opisa je također vidljivo da je ovaj način izražavanja povratnosti zajednički poljskom i hrvatskom pa nam stoga neće biti u središtu istraživanja u ovom radu, već ga ostavljamo za buduće usporedbe.

Treća su pojavnost u izražavanju povratnosti, koja je bitna razlika između hrvatskoga i poljskoga jezika, glagolske imenice koje su se razvile iz povratnih glagola, a primarno se tvore nastavcima -nie i -cie, npr. uczyć się 'učiti' > uczenie się 'učenje', poruszać się 'kretati se' > poruszanie się 'kretanje', dzielić się 'dijeliti se' > dzielenie się 'dijeljenje', starzeć się 'stariti' > starzenie się 'starenje', myć się 'prati se' > mycie się 'pranje', czesać się 〈češljati se〉 > czesanie się ‘češljanje〉. U poljskome se uz takve imenice u određenim upotrebama povratna oznaka zadržala, dok u hrvatskome takve slučajeve ne nalazimo.

Kao što smo u uvodnom poglavlju napomenuli, produktivnost je glagolskih imenica s povratnom oznakom się specifičnost poljskog jezika pa smatramo bitnim uključiti je u šire rasprave o nominalizaciji, kao i o povratnosti.

\section{Glagolske imenice i uloga się u procesu nominalizacije}

Glagolske imenice često se u literaturi ističu kao jedan od najproduktivnijih obrazaca nominalizacije, i to pogotovo one tvorene afiksom -nje (Šaravanja 2015). N. Pintarić (2010: 9-10) ističe da se u poljskom i hrvatskom radi o jednakim sufiksima - nie $=-n j e,-$ anie $=-$ anje,- cie $=c e$. U oba jezika, dakle, nalazimo jednake oblike imenica, ali pod različitim nazivima. Na primjer, Hrvatska gramatika (Barić i sur. 2005: 322) navodi naziv glagolske imenice i radne imenice uz objašnjenje da je glagolska imenica naziv koji se u morfologiji zadržava jer se ona tradicionalno uvrštava u glagolske oblike i odnosi se samo na imenice na -nje i -će derivirane od prijelaznih glagola, dok se naziv radna imenica koristi u tvorbi riječi za te iste imenice. ${ }^{5} \mathrm{U}$

4 Bitno je napomenuti da u tuđicama u istom značenju dolazi vezana osnova auto-, npr. autobiografia - autobiografija.

5 Šaravanja (2015) rabi naziv odglagolska imenica sinonimno s nazivom glagolska imenica, dok Birtić (2008: 93) upotrebljava naziv glagolska imenica govoreći o imenicama izvedenim sufiksom -nje i -će, ali i naizmjenično s nazivima odglagolska imenica i glagolska izvedenica. 
poljskom su glagolske imenice definirane kao nazivi radnji (nomina actionis, polj. nazwy czynności) koji se tvore s pomoću sufikasa -ni(e), -eni(e), -ci(e), kao npr. kopanie (piłki) 'udaranje (lopte)', pływanie 'plivanje', zmuszanie 'primoravanje', palenie 'paljenje/pušenje', poczęcie 'začeće', ukłucie 'ubod' (Nagórko 2012: 218). Njihov jezični status nije u cijelosti definiran, s obzirom na to da imaju imenički karakter i mijenjaju se kao imenice, a značenjski su bliske infinitivu. A. Nagórko navodi i da je tvorba glagolskih imenica (polj. gerundium) 6 gotovo u potpunosti kategorijalna te da one nasljeđuju obilježja glagola:

a) aspekt, npr. chwytanie.IPF/chwycenie.PF 'hvatanje', sprzatanie.IPF/ sprzatnięcie.PF 'spremanje', trafianie.IPF/trafienie.PF 'gađanje', urzq̨dzanie.IPF/ urządzenie.PF 'uređivanje'.7

b) povratnost, npr. chwalenie się dosl. 'hvaljenje se', golenie się dosl. 'brijanje se', upijanie się dosl. 'opijanje se' (Nagórko 2012: 2018).

Autori koji se bave nominalizacijom ujedno ističu dvojaku narav glagolskih imenica, koje preuzimaju određena sintaktička i semantička svojstva glagola s jedne, ali i imenica s druge strane (npr. Chomsky 1980, Birtić 2008, Rozwadowska 1997, Šaravanja 2015). Tako Koptjevskaja Tamm (2006: 653) ističe kako se nominalizirani oblici pojavljuju u tipičnim imenskim pozicijama u rečenici, pokazuju flektivna svojstva tipična imenicama (sklonidbu po broju i padežu), ali pokazuju neka ograničenja i sintaktička svojstva tipična za glagole, npr. imaju vlastite argumente, označavaju neku radnju ili događaj i sl. U opisima se poljskog i hrvatskogjezika dvojaka narav glagolskih imenica također ističe, posebice u raspravama o argumentnoj strukturi imenica (usp. Rozwadowska 1997, Birtić 2008, Šaravanja 2015).

Tako glagolske imenice često imaju vlastitu argumentnu strukturu, kao u primjeru (7) (Rozwadowska 1997: 41).

(7) Nagranie wywiadu z prezydentem przez dziennikarzy było mu nie na rękę. 'Novinarsko snimanje intervjua s predsjednikom nije mu išlo na ruku.'

Iz perspektive argumentne strukture się predstavlja zanimljiv problem jer se postavlja pitanje kako tumačiti njegovu ulogu u supojavljivanju s glagolskim imenicama. S jedne strane, się se pojavljuje s nekim glagolima koje bismo mogli smatrati

6 Nazivi gerund igerundium nastali su pod utjecajem latinskog nazivlja u gramatikama suvremenih jezika (usp. Haspelmath (1987), a posebice se uvode i pod utjecajem jezikoslovnih opisa engleskog jezika (-ing nastavka, npr. singing 'pjevanje'), posebice potaknuti studijom nominalizacije N. Chomskog (1970). U opisima se slavenskih jezika (npr. Sussex i Cubberley 2011) gerundom pak nazivaju mnogi oblici glagolskih priloga i pridjeva te stoga naziv gerund nije u potpunosti podudaran s pojmom glagolske imenice. Budući da nas u ovome radu zanimaju ponajprije glagolske imenice na -nje i -će te njihova tvorba u odnosu na preuzimanje povratne oznake się, koristit ćemo naziv glagolska imenica u svim sintaktičkim okruženjima u kojima se odabrani primjeri nalaze.

7 U poljskom se jeziku, za razliku od hrvatskoga, glagolske imenice mogu produktivno tvoriti od nesvršenih i svršenih glagola, što u nekim slučajevima otežava prevođenje poljskih imenica na hrvatski. Kada je razlika bitna, uputit ćemo na to u tekstu, a u slučajevima prijevoda koristit ćemo samo posvjedočene nesvršene oblike radi jasnijeg uspostavljanja prijevodne istovrijednosti. 
pravim povratnim glagolima, s obzirom na to da je agens jednak pacijensu, kao u primjerima (8) - (10).

(8) Jan się codziennie myje.

'Jan se svakodnevno pere.'

(9) Jan myje siebie codziennie.

'?Jan pere sebe svakodnevno.'

(10) Codziennie mycie się ( ${ }^{*}$ Jana).

'Svakodnevno pranje (*Jana/Janovo).'

S druge strane, się u poljskom u naglašenom obliku nikada ne dolazi kod glagolskih imenica ('golenie siebie 'brijanje sebe'). Taj je naglašeni oblik u poljskom, kao i u hrvatskom, načelno prihvatljiv kod pravih povratnih glagola (ujedno često služi kao dokaz prave povratnosti, v. Wilczewska 1966), što navodi na tumačenje da se prenosi u tvorbi u svojstvu bližem afiksu8 ${ }^{8}$, negoli zasebnom argumentu neke glagolske imenice. Kao takav ima i važnu ulogu u procesu leksikalizacije, što je svojstvo kojemu ćemo se posvetiti u kasnijim poglavljima analize.

\subsection{Opisi povratnih imenica u poljskom jeziku}

U jednom od rijetkih radova koji su posvećeni istraživanoj problematici, opisivanju se "povratnih" imenica (polj. rzeczowniki "zwrotne») posvetila H. Safarewiczowa (1954). Povratne se imenice, prema njezinu istraživanju, do 18. stoljeća javljaju izrazito rijetko, i to samo u opisnoj i znanstvenoj prozi. Tada počinje njihovo širenje i one postaju stalnom pojavom u književnom jeziku, dok ih u dijalektima ne nalazimo 9 .

Autorica (Safarewiczowa 1954: 334-335) uočava da se navedeni sufiksi anie, -enie, -cie i -ęcie nalaze u dvama tipovima imenica koje naziva predikatnima (polj. orzeczeniove), npr. sluchanie 'slušanje', mycie 'pranje' i subjektnima (polj. podmiotowe), npr. wzniesienie 'uzvišenje, uzvisina', 'povišeno mjesto', podanie 'molba', 'molba izražena u pismu, podnesak', okrycie 'ogrtač', 'kaput', zamknięcie 'brava, lokot', 'mali zasun, kračun'. Podjela koju predlaže odražava i jedno općenito svojstvo glagolskih imenica, a to je da su one slojevita kategorija u kojoj se mogu pronaći posve leksikalizirani oblici, oni koji zadobivaju nova značenja, npr. ispitivanje 'radnja u okviru istražnog postupka' (policijsko ispitivanje), ali i oni koji su izvedeni produktivno od glagola i s njime dijele temeljna značenjska obilježja, npr. propitivanje. Povratna oznaka się u pravilu dolazi s kategorijom predikatnih imenica,

8 Unizu radova o povratnosti Milenko Popovići Raisa I. Trostinska (1991, 1993, 2001, 2009) bave se statusom povratne oznake se u hrvatskom jeziku uspoređujući ju s postfiksom -sja u ruskom i ukrajinskom. Autori, za razliku od dotadašnjih tumačenja se kao zamjenice ili čestice, smatraju da se kod povratnih glagola radi o morfemu. S obzirom na to da u rečenici može zauzimati različite pozicije, a ne mora se nalaziti uz glagol, nazivaju ga morfemom satelitom. Isto obilježje, mogućnost promjene pozicije povratne oznake kod glagola, s hrvatskim dijeli i poljski jezik, za razliku od ruskoga i ukrajinskoga.

9 Kao što ćemo pokazati korpusnim istraživanjem, na mrežnom korpusu poljskog jezika, nalazimo ih i u supstandardnim uporabama. 
što također upućuje na njezinu ulogu kao pravilnoga i produktivnog afiksa koji se prenosi i čvrsto je vezan uz kategorije glagola. Zbog toga što sadrže obilježja glagola (aspekt, vrsta radnje i stanje), oblici na -anie ekspresivniji su od ostalih predikatnih imenica. Tako npr. pocałunek 'poljubac' može označavati radnju koja se vrši na kome jednostrano ili uzajamnu radnju, dok pocałowanie się 'ljubljenje' isključuje mogućnost jednostrane radnje (teoretski je moguće zamisliti da se radi o 'ljubljenju samoga sebe', ali praktična uporaba jezika ukazuje da se radi o uzajamnoj radnji) (Safarewiczowa 1954: 336).

Mjesto povratne oznake się u povratnih je imenica uvijek isto, ono se nalazi neposredno nakon imenice i nije moguće njezino premještanje. Iznimke od tog pravila moguće su u slučajevima gdje se dvije enklitike nalaze jedna uz drugu, preciznije dativ osobne zamjenice ( $m i$ ' $\mathrm{mi}$ ', ci 'ti', $m u$ 'mu') i akuzativ povratne zamjenice (się 'se'). Pri takvim konstrukcijama dativ osobne zamjenice dolazi ispred akuzativa povratne zamjenice, dakle između imeničkog i zamjeničkog dijela, kao u primjeru (11).

\section{(11) Jeden tylko był wyraźniejszy o tyle, że pani Barbara po chwili przygladania mu} sięzaczęła rozróżniaćsłowa. (Safarewiczowa 1954: 338)

'Samo je jedan bio jasniji, utoliko što je gospođa Barbara nakon kratkog promatranja počela razlikovati riječi.'

Prema J. Puzynini (1969: 104), razlozi za izostavljanje się ne pokazuju nikakvu pravilnost, već na njih utječu određeni čimbenici, kao npr. izbjegavanje dvoznačnosti, postojanje sinonimnih odglagolskih oblika, koje ipak ne objašnjavaju sve slučajeve nedostatka elipse. ${ }^{10} \mathrm{U}$ slučajevima u kojima se može javiti dvosmislenost, sięje nužno, kao u primjerima (12) i (13).

(12) Malowanie sprawiałojej widoczną przyjemność.

'Slikanje joj je pričinjalo vidljivo zadovoljstvo.'

(13) Malowanie się sprawiało Annie widoczną przyjemność.

'Šminkanje ${ }^{11}$ je Anni pričinjalo vidljivo zadovoljstvo.'

Rečenica (12) može funkcionirati umjesto (13) samo u slučajevima koji isključuju prijelazno, drugačije značenje.

Się se nikada ne upotrebljava uz glagolske imenice u pasivnom značenju (npr. dom się buduje 'kuća se gradi'), jer one i bez się izražavaju aktivno i pasivno stanje u značenjski ekvivalentnim konstrukcijama: (14) i (15)

10 Zanimljivo je da tome možemo posvjedočiti čak i u kategoriji reflexiva tantum, za koje Safarewiczowa (1954: 341) navodi da u načelu pri nominalizaciji zadržavaju povratnu oznaku się. Korpus je, naime, potvrdio i malen broj primjera s imenicama te kategorije bez się, iako se one u većini primjera pojavljuju sa się. Takve su imenice npr. pojawienie się.PF 'pojavljivanje' - pojawienie, przyjrzenie się.PF 'gledanje' - przyjrzenie, starzenie się 'starenje' - starzenie. Moguće je da je gubitak povratne oznake u primjerima podložan analogiji s drugim imenicama (iza kojih slijede imenice u genitivu), npr. Najczęściej przyczyna jest po prostu starzenie się organizmu. 'Najčešći je uzrok, jednostavno, starenje organizma.' / Za czynniki ryzyka uważa się starzenie organizmu i uwarunkowania genetyczne. 'Čimbenicima rizika smatra se starenje organizma i genetske predispozicije.'

11 Riječ je o istom leksemu koji bez povratne oznake znači 'slikanje, crtanje', a s povratnom oznakom 'šminkanje’. 
(14) Czycipowiedziano o tym, że buduje się u nas nową szkołę?

'Je li ti rečeno da se kod nas gradi nova škola?'

(15) Czy ci powiedziano o budowaniu u nas nowej szkoty? (= że budują szkołę = że szkołajest budowana $=\dot{z} e$ szkoła/szkołę siębuduje).

'Je li ti rečeno o građenju nove škole kod nas? (=da grade školu = da je škola građena = da se škola/školu gradi).'

\section{Metodologija i analiza povratnih imenica}

Kao što je iz pregleda opisa povratnih imenica u poljskom razvidno, analize se temelje na starijim tekstovima do polovice 20. stoljeća i predložene su klasifikacije i ograničenja uporabe oznake się uvelike vođene potrebama tradicionalnih gramatičkih opisa. Kako bismo neka od obilježja provjerili u suvremenome poljskom jeziku, odlučili smo se za korpusno utemeljeno istraživanje uz pomoć programa Sketch Engine i digitaliziranim mrežnim korpusom poljskog jezika (Polish Web 2012). Polish Web 2012 kao mrežni korpus sadrži suvremene tekstove koji nude uvid u standardne, ali i supstandarne uporabe povratnih imenica u različitim stilovima pa stoga mogu poslužiti kao nova građa na temelju koje se mogu izvući zaključci o čestotnosti i temeljnim obilježjima ove pojave. Cjelokupan broj pojavnica glagolskih imenica s povratnom oznakom się u korpusu je 4,122,396, od čega se 20 najučestalijih lema ostvaruje u četvrtini ukupnih pojavnica (25 \%), a kao početni smo fokus istraživanja odabrali prvih 100 po čestotnosti te smo neke manje učestale primjere uključili u kvalitativni opis budući da se navode kao tipični predstavnici određene kategorije povratnih glagola (npr. czesać się 〈češljati se)). S obzirom na to da się uz nominalizirani glagol u poljskom jeziku nema mogućnost promjene pozicije, tj. da uvijek dolazi neposredno iza nominaliziranog glagola, možemo pretpostaviti da se radi upravo o imenicama iza kojih się stoji kao njihov dio, a ne npr. o zasebnoj riječi 'się' koja se veže uz određeni glagol te je zamijenila svoju poziciju (usp.: On się boi. 'On se boji.' = On boi się. '* On boji se.'). Iako smatramo da je broj glagolskih imenica sa się koje se javljaju u korpusu nezanemariv, razlike između samih pojavnica u čestotnosti su velike. Tako samo prve tri povratne imenice broje više od 100,000 uporaba, dok ostale dolaze u manjem broju. Najfrekventnije su glagolske imenice sa się sljedeće: zapoznanie się. PF '(međusobno) upoznavanje' < zapoznać się 'upoznati se uzajamno', pojawienie się. PF 'pojavljivanje' < pojawić się 'pojaviti se', poruszenie się. PF 'kretanje' < poruszać się 'kretati se'. Prva tri primjera upućuju na raznorodnost povratnih glagola od kojih su imenice izvedene, po značenjskim i sintaktičkim obilježjima glagola (uzajamno značenje, inkoativnost, kretanje). Ostalih 100 najčešćih povratnih imenica također pokazuje značenjsku i sintaktičku raznolikost pa nam je stoga cilj istražiti postojanje sustavnih podskupina s obzirom na a) značenjska i sintaktička obilježja samih imenica, b) značenjska i sintaktička obilježja glagola od kojih su nastale i c) razlike u pojavljivanju glagolskih imenica sa i bez się. 
Govoreći o klasifikacijama povratnih imenica, bitno je istaknuti da je jedina predložena klasifikacija, koliko nam je poznato, ona Safarewiczowe (1954). Safarewiczowa (1954), koja dijeli povratne imenice u četiri značenjske grupe:

1. povratne imenice u pravom značenju te riječi, tj. one koje označavaju radnju čiji je vršitelj ujedno i primatelj/trpitelj - się ovdje znači 'siebie'

2. uzajamne imenice tj. one koje pokazuju da je radnja jednog vršitelja usmjerena na drugog - się ovdje znači 'ze sobą'

3. tzv. polj. nijakie ${ }^{12}$ imenice, u kojih zamjenica się samostalno ne vrši nikakvu funkciju, nego se značenjski u potpunosti veže uz imenicu - się tu znači nulu

4. terminativne imenice, koje iskazuju visok stupanj intenziteta, graničnu točku ili postignuće rezultata dane radnje - formalni su pokazatelj te kategorije dva čimbenika: prefiks i povratna zamjenica się.

Predložena klasifikacija odražava i neke problematične točke u opisu povratnih glagola i uloge się/se kao vrste riječi. Naime, poznato je da się i se mogu biti definirane kao zamjenica ili kao čestica ovisno o njihovoj funkciji u svezi s glagolom (npr. Belaj 2011, Oraić Rabušić 2018, Wilczewska 1966). Tako i kod imenica možemo naići na isti problem jer se razlike ostvaruju na semantičkoj razini s jedne strane ( $u$ vidu prave, tj. semantičke povratnosti, kao u skupini 1) ili pak u vidu się/se kao sintaktičkog elementa koji je gramatikaliziran kao značenjski prazna čestica, kao u skupini 3). K tomu želimo pridodati i leksičku perspektivu, i to iz dva aspekta. S jedne strane, oznaka się okamenjeni je i neodvojivi dio glagola koji pripadaju skupini reflexiva tantum. S druge strane, ona može služiti i pri tvorbi novih leksičkih jedinica u kojima dodatak się tvori novu leksičku jedinicu, s novim značenjem, različitim od nepovratnog parnjaka. U hrvatskim se opisima ističe i uloga se kao dijela cirkumfiksa koji zajedno s prefiksom također tvori novi leksički oblik (Tafra i Košutar 2009). S potonjom se ulogom može povezati skupina terminativnih imenica koju predlaže Safarewiczowa. Stoga smatramo da je njezina klasifikacija podložna daljnjim opisima i prilagodbama kako bi se svojstva povratnih glagola mogla dovesti u neposrednu vezu s povratnim imenicama. Posebno je važno istaknuti da su navedena obilježja češće istraživana u podjelama hrvatskih povratnih glagola negoli poljskih (uziznimku Wilczewske), ali smatramo da se ona mogu primijeniti kao svojevrsnitertium comparationis i na poljske glagole, kao i na određena svojstva povratnih imenica.

\subsection{Semantička povratnost i povratne imenice}

Semantička je povratnost ona pri kojoj radnja prelazi na njenog vršitelja, objekt radnje istovremeno je i njezin subjekt, dakle agens je jednak pacijensu. To znači da povratna oznaka się/se kod takvih radnji ima ulogu zamjenice te je jedna-

12 Naziv nijakie problematičan je jer u poljskom jeziku sama riječ znači 'nikakav'. Njezina se upotreba javlja i u gramatičkoj terminologiji, gdje rodzaj nijaki označuje 'srednji rod'. 
ka zamjenici siebie/sebe (Wilczewska 1966, Geniušienè 1987, Nagórko 1998, Belaj 2001, Barić et al. 2005, Silić i Pranjković 2007, Bańko 2012). Tradicionalni je naziv u hrvatskoj literaturi za glagole koji su nositelji takve radnje pravi povratni glagoli. Belaj (2001) predlaže drugačiju podjelu povratnih glagola te ove glagole naziva tercijarnopovratnima (uz primarnopovratne i sekundarnopovratne), jer su najudaljeniji od prototipa, budući da kod njih se ima isključivo sintaktičku ulogu, a nije vezan uz glagol morfološki ili leksički. U poljskom kod Wilczewske (1966) nalazimo naziv neposredno povratniglagoli13.

Tipični su predstavnici semantičke povratnosti glagoli koji označuju radnju usmjerenu na površinu vlastitog tijela, kao npr. czesać się «češljati se», golić się 'brijati se', gładzić się 'gladiti se', myć się 'prati se', pudrować się 'pudrati se'. U prvih 100 imenica sa się treba istaknuti imenicu ubieranie się 'oblačenje, odijevanje' < ubierać się 'oblačiti se, odijevati se'. Navedenu povratnu imenicu Puzynina (1969: 104) ubraja među povratne glagole koji označuju toaletne radnje (kao i myć się, czesać się itd.) te ističe da oni imaju tendenciju elipse povratne oznake pri nominalizaciji. Međutim, pregledom uporaba u korpusu možemo uočiti da się ima razlikovnu ulogu u srodnim kontekstima, kao u primjerima:

(16) [...] jeśli zatem widzimy, że nasze dziecko trzyma się w grupie, która nie prezentuje zbyt dobrego stylu, to możemy spodziewać się, iż właśnie to jest przyczyna takiego, a nie innego sposobu ubierania się naszego dziecka.

'[...] ako zatim vidimo da se naše dijete drži grupe koja ne prezentira baš dobar stil, možemo očekivati da je upravo to uzrok takvoga, a ne drugačijeg načina oblačenja našeg djeteta.'

(17) Przewijanie, ubieranie dziecka traktujjakzabawę [...]

'Previjanje, oblačenje djeteta tretiraj kao zabavu [...]'

U prvom primjeru riječje o djetetu koje samo sebe oblači, dokje u drugom primjeru riječ o roditelju koji vrši radnju oblačenja nad djetetom. Slične razlike mogu se pronaći kod glagola osobne higijene, poput czesać się, myć się.

(18) [...] gdy doskonala się czynności manualne dziecka [...] tj.jedzenie tyżka, widelcem, czesanie się, myciezębów, rysowanie [...]

[...] kada se usavršavaju manualne radnja djeteta [...] tj. jedenje žlicom, vilicom, češljanje, pranje zuba, crtanje [...]

Navedene razlike u sintaktičkim okvirima povratnih imenica sa się ili s imenicom u genitivu navode na zaključak da se derivacijski obrasci ovih glagolskih imenica tvore od dvaju različitih glagola, točnije onih prijelaznih u jednom ili onih neprijelaznih (povratnih) u drugom slučaju. Takav uvid nije moguće dobiti u hrvatskom jeziku budući da se povratna oznaka se ne prenosi pri nominalizaciji povratnih gla- 
gola, iako je to donekle usporedivo s primjerima u kojima se ostvaruju dodatni argumenti imenica naspram onih u kojima se ne ostvaruju, npr. svakodnevno češljanje dugodlakih pasmina je bitno. U vidu pojavljivanja oznake się i razlikovne uloge, moramo istaknuti da ona pruža uvid i u to da je riječ o dvama različitim leksičkim jedinicama, prijelaznom i povratnom glagolu, ali i da się u slučajevima semantičke povratnosti kod imenica nije moguće zamijeniti zamjenicom siebie, kao što se načelno smatra mogućim kod glagola. U tome nas ona navodi i na još jednu funkciju, koju za hrvatski jezik ističe i Oraić Rabušić (2018), a to je da se i u slučajevima semantičke povratnosti się ponaša kao čestica ${ }^{14}$.

\subsection{Kategorija uzajamnosti i povratne imenice}

Kategorija uzajamnosti (recipročnosti) jedna je od problematičnih kategorija za jednoznačnu definiciju u onim jezicima u kojima je oznaka povratnosti istovremeno i oznaka uzajamnosti. Iznimka za problem određivanja uzajamnih glagola nisu ni hrvatski ni poljski jezik. König i Gast (2008: 12) upućuju na činjenicu da se uzajamnost i povratnost ne mogu uvijek gledati ravnopravno zato što kod uzajamnosti (nužno) nalazimo više surečenica u iskazu, što nije slučaj s povratnošću. To vidimo u primjeru:

(19) On me udario i ja sam udario njega. $=$ Mi smo udarali jedan drugoga. = Mi smo se udarali (tukli međusobno).

U raznim se drugim jezicima, primjerice romanskima i starogrčkom, a i u drugim slavenskim jezicima, uzajamnost radnje može iskazati istim sredstvima kao i povratnost, no npr. u engleskom se ona iskazuje recipročnim zamjenicama, a u turskom posebnim sufiksima koji nisu isti kao sredstva za izražavanje recipročnosti, što se vidi u sljedećim primjerima (Marković 2013: 207-208):

(20) engl. Adam and Eve blamed themselves. (REFL.)

(A. i E. okrivljivali su se (svaki sebe).)

(21) Adam and Eve blamed each other. (RECIP.)

(A.i E. okrivljivali su se (jedno drugo).)

(22) tur. Sultan ve Şeherazad sev-in-ir-ler. (-REFL-PRES-3.PL)

(Sultan i Šeherezada se raduju.)

(23) Sultan ve Şeherazad sev-iş-ir-ler. (-RECIP-PRES-3.PL)

(Sultan iŠeherezada se vole.)

14 Oraić Rabušić (2018) kaže da u hrvatskom, a povodi se za češkim, se i sebe i uz prave povratne glagole (semantička prijelaznost) nisu istovjetni, i kod pravih povratnih glagola se je čestica, a sebe zamjenica. Nemogućnost zamjene se i sebe u kontekstima s pravim povratnim glagolima dokazuju i poljske povratne imenice. 
Navedeni nam primjeri pokazuju raznovrsnost sredstava za izražavanje uzajamnosti radnje u različitim jezicima. Prema tom bismo prikazu mogli reći da se hrvatski i poljski po mogućnostima njezina iskazivanja nalaze između engleskoga i turskoga. Dakle, hrvatski i poljski s engleskim dijele sintagmu each other - jedno drugo - jeden drugiego za iskazivanje uzajamnosti, dok se u sredstvima za iskazivanje povratnosti razlikuju: themselves $\neq$ się/se. Turski se, s druge strane, svojim zasebnim sufiksima za svaku od navedenih kategorija (povratnost i uzajamnost), razlikuje od hrvatskog i poljskog u potpunosti, budući da u hrvatskom i poljskom jedno sredstvo - povratna oznaka się/se - može izraziti obje kategorije, doku turskom za svaku navedenu kategoriju postoji posebno sredstvo, zasebni sufiksi navedeni u primjerima (22)i (23).

Kao što smo naveli, Safarewiczowa (1954) ističe da je jedna od skupina povratnih imenica ona čiji su predstavnici izvedeni od glagola uzajamnog značenja i naziva ih uzajamnim imenicama. Među prvih 100 imenica u korpusu to su: dogadanie się. PF 'dogovaranje, sporazumijevanje' < dogadać się 'dogovoriti se, sporazumjeti se', umówienie się. PF 'dogovaranje’ < umówić się 'dogovoriti se', porozumiewanie się. IPF 'sporazumijevanje' < porozumiewać się 'sporazumijevati se', komunikowanie się. IPF 'komuniciranje' < komunikować się 'komunicirati'. Vidi se da su sve navedene imenice derivirane iz komunikacijskih glagola koji podrazumijevaju najmanje dva člana koji vrše radnju međusobno. Primjeri pokazuju da glagoli uzajamno povratnog značenja to značenje zadržavaju i pri nominalizaciji te da ono postaje obilježje deriviranih imenica, kao u primjerima:

(24) Pozostaje próba dogadania się z uciążliwym sąsiadem.

'Ostaje pokušaj dogovaranja (sporazumijevanja) s problematičnim susjedom.'

(25) Problemy komunikacyjne - trudności w nawiqzzywaniu kontaktu i porozumiewaniu sięz rówieśnikami oraz z rodziną.

'Komunikacijski problemi - poteškoće u ostvarivanju kontakta i sporazumijevanju s vršnjacima i s obitelji.'

Navedeni glagoli, a posljedično i imenice izvedene od njih, mogu funkcionirati i bez povratne oznake, u prijelaznom obliku s dopunom u genitivu, kao u sljedećim primjerima:

(26) Serwis zapewnia możliwość błyskawicznego kontaktu z właścicielem i dogadanie ewentualnych szczegótów.

'Servis osigurava mogućnost brzog kontakta i dogovaranje eventualnih detalja.'

To su obilježja koja su zajednička i hrvatskim imenicama izvedenim iz ekvivalentnih glagola, što potvrđuje mrežni korpus hrvatskog jezika hrWaC: 
(27) Jedan od zadataka novog vodstva bit će i dogovaranje povoljnijih uvjeta korištenja školske sportske dvorane za klubove koji ju koriste.

(28) Uželji što kvalitetnijeg komuniciranja rezultata provedbe, kako EE projektau cijelosti, tako i njegovih sastavnica [...]

Međutim, postoje i imenice koje nisu zadržale povratnu oznaku, ali nose uzajamno značenje s pomoću drugih jezičnih sredstava, poput prijedložno-padežnog izraza u (29) i pridjeva u (30).

(29) Przewodniczacy Rady zapytał czy w kwestii ustalenia kwoty za zamianę było to dogadanie między właścicielem a Burmistrzem?

'Predsjedavajući Vijeća upitao je je li pri utvrđivanju kvote za zamjenu to bilo dogovaranje između vlasnika i gradonačelnika?'

(30) Być może więc i z tego powodu wzajemne komunikowanie w sieci pozostaje bezosobowe.

'Možda, dakle, i iz tog razloga uzajamno komuniciranje u mreži postaje neosobno.'

To pokazuje da je uzajamnost podložna ograničenom broju slobodnih varijacija s pomoću različitih sredstava kojima se ona izražava.

\subsection{Się kao sintaktički, tvorbeni i leksikalizacijski element}

Osim semantičke povratnosti i uzajamnog značenja, povratna oznaka u hrvatskom i poljskom jeziku može imati i funkcije sintaktičkog i tvorbenog elementa. To je vidljivo u glagola koji mogu funkcionirati i kao prijelazni (dakle, s dopunom u akuzativu) i kao povratni, s time da je naglašena razlika između povratnih glagola i njihovih nepovratnih parnjaka u sintaktičkom okviru i usmjerenosti događaja, npr. buditi Anu : buditi se uz Anu // budzić Annę: budzić sięobokAnny.

Geniušienè (1987: 30-31) navodi da povratna oznaka može imati dvije funkcije: a) semantičku funkciju, pri kojoj markira promjenu značenja i b) sintaktičku funkciju, pri kojoj markira promjenu sintaktičkog okvira. Te funkcije nisu nužno povezane, iako kod većine povratnih glagola povratna oznaka ima obje funkcije, isto tako može imati i samo semantičku funkciju (kao u španjolskom morir 'umrijeti prirodnom ili nasilnom smrću' $\rightarrow$ morir-se 'umrijeti prirodnom smrću'), samo sintaktičku funkciju (ruski On zažmuril glaza. / On zažmuril-sja. 'Zažmirio/zaškiljioje (očima). / Zažmirio/zaškiljio je.') ili nijednu od njih (litavski Jis sédo prie stal-o. / Jis sèdo-si prie stalo. 'Sjeo je za stol. / Sjeo se je za stol. ${ }^{15}$ ').

Ova potonja, sintaktička funkcija, može se vezati uz treću skupinu povratnih imenica koje Safarewiczowa (1954) naziva nijakie imenice, odnosno uz one u kojih się nema samostalno značenje, već se u potpunosti veže uz imenicu. Się kao ozna-

Konstrukcija sa se rabi se ponajprije u kajkavskom narječju. 
ka detranzitivizacije postaje u potpunosti funkcionalna oznaka, gramatikalizirana, kako bi služila promjeni sintaktičkog okvira glagola, ili pak razlici u valencijama glagola (iz toga razloga Šojat (2008: 194-201) zagovara zasebne unose povratnih glagola u leksikografskim resursima). Dakle, ona ne može ni u kojem slučaju biti zamijenjena naglašenim oblikom sebe/siebie. Međutim, i unutar ove skupine glagola nalazimo neke sustavne razlike. Načelno, ta se glagolska skupina može podijeliti na glagole koji unutar sebe zadržavaju svoje značenje kada uz njih stoji se/się, i na one koji u tom slučaju mijenjaju značenje. Primjerice, prvoj grupi pripadaju glagoli poput budzić 'buditi - budzić się 'buditi se', straszyć 'plašiti' - straszyć się 'plašiti se', denerwować «živcirati - denerwować się 〈živcirati se’, a drugoj glagoli poput policzyć 'pobrojiti' - policzyć się 'obračunati se, tłumaczyć 'prevoditi' - tłumaczyć się 'opravdavati se, izgovarati se', podać 'dati, dodati' - podać się 'predstaviti se (ob. lažno)'.

Dakle, vidimo da u prvoj skupini glagola się/se primarno mijenja sintaktički okvir glagola, a u drugoj stvara novo značenje glagolskoga oblika.

U korpusu smo provjerili prenose li se navedena obilježja glagola na imenice izvedene od tih glagola. Između prvih 100 povratnih imenica, nalaze se 52 derivirane od glagola koji pokazuju tzv. nepravu povratnost. Neke su od njih izvedene od glagola koji su reprezentativni za prvu podskupinu, tj. onu u kojih je się detranzitivizirajući element koji ne doprinosi promjeni temeljnog glagolskog značenja. Takvi su primjerice: przygotowanie się 'pripremanje' < przygotować się 'pripremiti se', włączenie się. PF 'uključenje '< właczyć się 'uključiti se', trzymanie się 'držanje' < trzymać się 'držati se', zatrzymywanie się 'zadržavanje' < zatrzymywać się 'zadržavati se', otwarcie się. PF 'dosl. otvorenje' < otworzyć się 'otvoriti se'.

Jedan od primjera koji pokazuje razlike u sintaktičkim okvirima što se prenose i na povratne imenice, odnosi se na oblik przygotowanie się.PF 'pripremanje' < przygotować się 'pripremiti se'.

(31) Każda kolejna osoba miała osiem minut naprzygotowanie się iosiem minut na przeprowadzenie prezentacji dydaktycznejna zadany temat.

'Svaka sljedeća osoba imala je osam minuta za pripremu i osam minuta za održavanje didaktičke prezentacije na zadanu temu.'

(32) Opis potrzeb i wymagań umożliwiający przygotowanie się wykonawców do udziału w dialogu [...]

'Opis potreba i zahtjeva koji omogućuju pripremu izvršitelja za sudjelova je u dijalogu [...]'

(33) Po pierwsze, zaoczny system przygotowania kandydatów prowadził do obniżenia poziomu ich kwalifikacji.

'Kao prvo, večernji obrazovni sustav pripremanja kandidata doveo je do smanjenja razine njihove kvalifikacije.'

Kao što se vidi iz hrvatskih prijevoda, przygotowanie się bolje odgovara imenici priprema, koja se odnosi na samostalno pripremanje samih sudionika radnje, dok 
nepovratna imenica przygotowanie i u hrvatskom ima svoj prijevod u glagolskoj imenici iza koje slijedi imenica u genitivu.

Kod ove skupine zamjetne su i neke tendencije u razlikovnoj ulozi się u povratnih imenica. Uzmemo li primjer otwarcie się 'dosl. otvorenje' < otworzyć się 'otvoriti se', možemo uočiti razlike u kontekstu ovisno o tome postoji li voljan i svjestan vršitelj radnje 'otvorenja (vrata)' naspram fokusa na (spontano) 'otvorenje', kao u primjerima (34) - (36). Važno je napomenuti da imenicu otwarcie się prevodimo doslovno sa 'otvorenje', jer je izvedena od svršenog glagola otworzyć się 'otvoriti se'. Iako u hrvatskom postoji imenica otvorenje, ona se odnosi na čin kojim se otvara neka javna ustanova ili događaj, a ne npr. vrata. To je u svezi s razlikom između hrvatskog i poljskog prema kojoj se u hrvatskom od nesvršenog vida glagola mogu gotovo bez ograničenja tvoriti glagolske imenice na -nje, dok u svršenom postoje određena ograničenja (v. Birtić 2008, Šaravanja 2015).

(34) Zamontowany zamek powinien gwarantować otwarcie się drzwi poprzez ich lekkie pchnięcie.

'Montirana brava trebala bi jamčiti otvaranje vrata laganim guranjem.'

(35) Nagłe otwarcie się drzwi całkowicie ja zaskoczyło - po raz kolejny w ciagu kilku minut.

'Naglootvaranjevrataupotpunostijujeiznenadilo-većdrugiputunekoliko minuta.'

(36) Zadaniem zakładnika było tylko otwarcie drzwi, Levan i Wasilij ustawili się po obu stronach.

'Zadaćom talaca bilo je samo otvaranje vrata, Levan i Wasilij smjestili su se na obje strane.'

Primjeri (34) i (35) pokazuju da povratna imenica dolazi u kontekstima u kojima nije nužno naglasak na svjesnom vršitelju radnje 'otvaranja vrata', dok primjer (36), u kojem se nalazi nepovratna imenica, upućuje upravo na vršitelja radnje. Stoga bismo mogli zaključiti da się, iako prema Safarewiczowoj (1954) ne znači ništa, uvodi neke značenjske razlike u širem značenjskom i sintaktičkom kontekstu, poput fokusiranja na svojstva voljnosti vršitelja radnje.

Naime, się u drugoj skupini glagola, osim promjene sintaktičkog okvira, uvodi i veću značenjsku razliku te ga se može promatrati i kao tvorbeni element, odnosno element leksikalizacije. Promatranje povratne oznake se u hrvatskom kao jednog od morfosintaktičkih sredstava na raspolaganju u procesu leksikalizacije zagovara Raffaelli (2016) na primjerima glagola ugledati (koga ili što) i ugledati se na (koga ili što). U prvom je slučaju, prema mišljenju autorice, riječ o glagolu percepcije, npr. ugledati pticu na stablu, dok je u drugome riječ o metaforičkome proširenju značenja glagola, npr. ugledala se na svoje učitelje. Značenjsko proširenje ne ovisi isključivo o promjeni pojmovnoga sadržaja toga glagola, već i o morfosintaktičkim sredstvima (se i prijedlogu na) bez kojih novo, metaforički utemeljeno značenje ne bi bilo mo- 
guće iskazati. Stoga se primjeri poput ugledati se na mogu smatrati složenim leksičkim izrazima u kojih je upravo se ona jezična jedinica koja djelatno mijenja značenje glagola, a naravno i njegovu sintaktičku okolinu (u smislu da povratni glagol ne može uzimati iste dopune kao i njegovi prijelazni nepovratni parnjaci). Poljski pokazuje veoma slične tendencije pri oblikovanju značenja glagola kao i hrvatski, ali ga zadržava i u kategoriji povratnih imenica.

Neki su primjeri imenica izvedenih od glagola čije se značenje mijenja kada uz njih dolazi się:

stanie się 'postajanje' < stać się 'dogoditi se, postati' / stanie 'stajanje' < stać 'stajati';

zajmowanie się 'bavljenje' < zajmować się 'baviti se' / zajmowanie 'zauzimanje' < zajmować 'zauzimati, obuhvaćati';

zapisanie się.PF 'upisivanje, učlanjenje' < zapisać się 'upisati se, učlaniti' / zapisanie 'zapisivanje (olovkom)' < zapisać 'zapisati, zabilježiti'.

Kao što se iz primjera vidi, mogu se izdvojiti i podslučajevi: u prvima je riječ o bliskosti događaja (npr. 'učiti' - 'poučavati', 'zapisati se' - 'upisati se'), u drugima je često riječ o (metaforički) povezanim značenjima (stajanje kao fizička radnja i postajanje kao apstraktni proces). I jedni i drugi u rječnicima se bilježe kao zasebni leksemi, npr. Nowy stownikjęzyka polskiego (2003: 951-952) razlikuje rječničke natuknice stać i stać się. ${ }^{16}$ Stoga, iako Puzynina (1969) navodi da się služi kao element kojim se isključuje nepoželjna dvoznačnost u nekom kontekstu, smatramo da je prikladnije gledati się kao jezično sredstvo kojim se proizvodi višeznačnost leksema i omogućuje govornicima stvaranje imenskog izraza sa się koje ga značenjski i sintaktički obogaćuje.

\section{Zaključak}

U radu smo istražili pojavu specifičnu za poljski jezik, tzv. povratne imenice. Povratnost je jezično obilježje koje se najčešće veže uz glagole, no u poljskom se, kao i u češkom, za razliku od ostalih slavenskih jezika, nalazi i u imenica izvedenih od povratnih glagola. One su u procesu nominalizacije zadržale sredstvo kojim se povratnost izražava, povratnu oznaku się, stoga čine produktivnu skupinu, što je potvrdilo korpusno istraživanje.

Primjeri iz korpusa pokazali su raznorodnost poljskih povratnih imenica prema njihovim sintaktičkim i semantičkim obilježjima. Ovisno o vrsti povratnosti

16 Slično kao i u hrvatskim leksikografskim resursima, bilježenje glagolskih imenica nije dokraja usustavljeno. Primjerice, u Hrvatskom jezičnom portalu, http://hjp.znanje.hr, dio glagolskih imenica naveden je kao dio natuknice koja obično upućuje na glagol (npr. stajanje), a dio kao imenica s novim značenjem specifičnim u odnosu na glagol (npr. otvorenje), a dio samo kao nastavci u pravilnoj tvorbi glagolskih priloga, pridjeva iimenica (npr. kretanje). Takva je situacija prisutna i u poljskom leksikografskim resursima, gdje i Nowy stownik języka polskiego (2003) imenicu stanie się bilježi pod natuknicom glagola stać się. 
koja se izriče glagolima od kojih su imenice derivirane, njihovi se sintaktički okviri razlikuju. Tako je različitost sintaktičkog okvira povratnih imenica izvedenih od glagola kojima se izriče semantička povratnost i njihovih nepovratnih parnjaka uputila na različitost sintaktičko-semantičkih obilježja ishodišnih glagola. Budući da je się u poljskom jeziku ujedno i oznaka uzajamnosti radnje, glagolske su imenice izvedene od glagola uzajamnog značenja pokazale da se isto obilježje zadržava te iskazuje drugim sredstvima i u određenim slučajevima u kojima imenica ne zadržava się. Najbrojnija skupina imenica, one derivirane od glagola koji imaju nepovratne parnjake, ali ne iskazuju semantičku povratnost, pokazale su da, ovisno o tome unosi li się promjenu značenja u glagol, ta se promjena prenosi i na imenicu. Dakle, u nekim slučajevima povratna oznaka mijenja sintaktičko okruženje nominaliziranog glagola, dok u drugima utječe i na promjenu značenja glagolske imenice, tj. vrši funkciju tvorbenog elementa.

Istraživanje je pokazalo da u poljskom jeziku povratnost nije svojstvena samo glagolima, nego se procesom nominalizacije prenosi i na imenice. Iako se povratna oznaka się ne prenosi uvijek na imenice derivirane od povratnih glagola, moguće je utvrditi određene pravilnosti pri njezinu zadržavanju uz imenicu te je vidljivo da povratne imenice u određenoj mjeri zadržavaju svojstva glagola od kojih su derivirane. Stoga se nadamo da smo ovim istraživanjem uputili na složenost kategorije povratnosti, podložne daljnjim poredbenim proučavanjima slavenskih jezika.

\section{Popis literature}

Babić, Stjepan (2002). Tvorba riječi u suvremenome hrvatskome jeziku. Zagreb: Hrvatska akademija znanosti i umjetnosti i Nakladni zavod Globus

Bańko, Mirosław (2012). Wykłady z polskiejfleksji. Warszawa: Wydawnictwo Naukowe PWN

Barić, Eugenija, Mijo Lončarić, Dragica Malić, Slavko Pavešić, Mirko Peti, Vesna Zečević i Marija Znika (2005). Hrvatska gramatika. Zagreb: Školska knjiga

Belaj, Branimir (2001). Prototipnokontekstualna analiza povratnih glagola u hrvatskom jeziku. Suvremena lingvistika 51-52 (1-2): 1-11

Birtić, Matea (2008). Unutarnja struktura odglagolskih imenica u hrvatskome jeziku. Zagreb: Institut za hrvatski jezik i jezikoslovlje

Chomsky, Noam (1970). Remarks on nominalization. Jacobs, Roderic A. i Peter S. Rosenbaum (ur.). Readings in English Transformational Grammar. Waltham. Mass.: Ginn and Co., 184-221

CODL 2013 = Matthews, P. H. (2013). The Concise Oxford Dictionary of Linguistics. Oxford: Oxford University Press

Geniušienė, Emma (1987). The Typology of Reflexives. Berlin-New York-Amsterdam: Mouton de Gruyter

GWJP. Morfologia 1984 = Grzegorczykowa, Renata, Roman Laskowski i Henryk Wróbel (ur.) (1984). Gramatyka wspótczesnego języka polskiego. Morfologia. Warszawa: Państwowe Wydawnictwo Naukowe 
Haspelmath, Martin (1987). Verbal noun or verbal adjective? The case of latin gerundive and gerund. Arbeitspapier Nr.3. Köln: Institut für Sprachwissenschaft

Hrdlička, Miroslav i Ivana Vidović Bolt (2019).Zašto hrvatski i poljski »glagolski pridjevi radni« nisu ekvivalentni? Pintarić, Neda, Čagalj, Ivana i Ivana Vidović Bolt (ur.). Komparativnoslavističke lingvokulturalne teme. Zagreb: Srednja Europa, 121-129

Hron, David (2005). On the Derivation of Reflexive Nouns: the Case of Czech. htttp://linguistics.huji.ac.il/IATL/22/Hron.pdf (pristup 3. lipnja 2019)

Koptjevskaja-Tamm, Maria (2006). Nominalization. Brown, Keith (ur.). Encyclopedia of Language and Linguistics. Amsterdam-Boston: Elsevier Science, 652-659

König, Ekkehard i Volker Gast (2008). Reciprocals and reflexives: Typology, description and theory. König, Ekkehard i Volker Gast (ur.). Reciprocals and reflexives: Theoretical and Typological Expolorations. Berlin-New York: Mouton de Gruyter

Letuchiy, Alexander (2011). Reciprocity and similar meanings in Slavic languages and SAE. Kosta, Peter i Lilia Schürcks (ur.). Formalization of Grammar in Slavic Languages. Frankfurt am Main: Peter Lang, 297-314

Marković, Ivan (2013). Uvod u jezičnu morfologiju. Zagreb: Disput

Matasović, Ranko (2011). Croatian Reflexive Constructions from the Historical Point of View. (rukopis)

Nagórko, Alicja (1998). Zarys gramatyki polskiej (ze słowotwórstwem). Warszawa: Wydawnictwo Naukowe PWN.

Oraić Rabušić, Ivana (2018). Struktura povratnih glagola i konstrukcije sa se u hrvatskome jeziku. Zagreb: Institut za hrvatski jezik i jezikoslovlje

Pintarić, Neda (2010). Kontrastivno rječotvorje: imenička tvorba u tablicama. Zagreb: Filozofski fakultet u Zagrebu

Popović, Milenko i Raisa Ivanovna Trostinska (1991). O glagolskom se u hrvatskosrpskom (i analogu u ruskom i ukrajinskom). Radovi zavoda za slavensku filologiju. 26: 23-26.

Puzynina, Jadwiga (1969). Nazwy czynności we współczesnymjęzyku polskim (słowotwórstwo, semantyka, składnia). Warszawa: Państwowe wydawnictwo Naukowe

Raffaelli, Ida (2016). Morfosemantička obilježja percepcijskih glagola u hrvatskom. Botica, Stipe, Davor Nikolić, Josipa Tomašić i Ivana Vidović Bolt (ur.). Šesti hrvatski slavistički kongres. Zbornikradova (Prvi svezak). Zagreb: Hrvatsko filološko društvo-Hrvatski slavistički odbor, 375-387

Rozwadowska, Bożena (1997). Towards a Unified Theory of Nominalizations. External and Internal Eventualities. Wrocław: Wydawnictwo Uniwersytetu Wrocławskiego

Safarewiczowa, Halina (1954). Rzeczowniki »zwrotne« wjęzyku polskim. Język polski 5: 332348

Schladt, Mathias (2000). The typology and grammaticalization of reflexives. Frajzynger, Zygmunt i Traci S. Curl (ur.). Reflexives: forms and functions. Amsterdam/Philadelphia: John Benjamins Publishing Company, 103-124

Silić, Josip i Ivo Pranjković (2007). Gramatika hrvatskoga jezika za gimnazije i visoka učilišta. Zagreb: Školska knjiga

Sobol, Elżbieta (2003). Nowy słownik języka polskiego. Warszawa: Wydawnictwo Naukowe PWN. 
Sussex, Roland i Paul Cubberley (2011). The Slavic Languages. Cambridge: Cambridge University Press

Šaravanja, Lidija (2015). Fleksibilnost argumentne strukture odglagolskih imenica na -nje. Mostariensia: časopis za društvene i humanističke znanosti 19 (1): 45-57

Šojat, Krešimir. Sintaktički i semantički opis glagolskih valencija u hrvatskom. Neobjavljeni doktorski rad. Zagreb: Filozofski fakultet Sveučilišta u Zagrebu.

Tafra, Branka i Petra Košutar (2009). Rječotvorni modeli u hrvatskom jeziku. Suvremena lingvistika 67: 87-107

Wilczewska, Krystyna (1966). Czasowniki zwrotne we wspótczesnej polszczyźnie. Toruń: Towarzystwo Naukowe w Toruniu

\section{Reflexivity as a nominal category: the case of Polish reflexive nouns}

This study deals with "reflexive nouns « in Polish, i.e. deverbal nouns which retain the reflexive marker sie in the process of nominalization. We compare syntactic and semantic features of reflexive verbs with their noun counterparts and examine specific properties of each subgroup with usage-based data from the Polish Web corpus 2012. The study shows that certain properties of different subgroups of reflexive verbs are transferred to reflexive nouns, but also points to some specificities and differences of this category, as well as differences between Polish and other Slavic languages in the expression of reflexivity as a nominal category.

Ključne riječi: povratnost u jeziku, povratne imenice, nominalizacija, poljski jezik Keywords: reflexivity, reflexive nouns, nominalization, Polish 